\title{
AN ANALYSIS STUDENTS' ABILITY IN IDENTIFYING MAIN IDEA IN NARRATIVE PARAGRAPH OF THE FIRST GRADE AT SMA PUTERI SION MEDAN
}

\author{
Deniati Sitohang, Damerita Damanik, Kembar Rosari Capah, Resperdiana Purba. \\ English education prima Indonesia university \\ Deniatisitohang@gmail.com,Dameritadamanik98@gmail.com, Kembarrosari27@gmail.com, \\ Presperdiana@gmail.com.
} Submitted: 2021-03-01

Accepted: 2021-05-01

\begin{abstract}
This study aims to provide an overview of the analysis of class X SMA Puteri Sion Medan in identifying and knowing the difficulties experienced by class X Puteri Sion students in determining the main ideas in the narrative paragraphs. This research uses a qualitative approach,and the tool of data collection was used written test. The sample consisted of 11 students. In conducting the research, the researcher got the result that the students' ability to identify main ideas in narrative paragraphs was in a very bad category. Based on the analyzed data, it was found that 3 students $(27.28 \%)$ got a score of 81-90 (very good), 1 student (9.09\%) got a score of 61-70 (enough), 2 students (18.18\%) got a score grades 51-60 (poor), and 5 students (45.44\%) scored less than 50 (very bad). Most of the students scored in the very poor category. After analyzing the ability to identify main ideas in narrative paragraphs, it is known that the ability to identify main ideas in class X Puteri Sion Medan is in a very bad category. The difficulties that students face when identifying the main idea in a narrative paragraph are a lack of interest in learning that makes them lazy to read, lack of vocabulary knowledge, their vocabulary is very small, and poor reading strategies.
\end{abstract}

Keywords: Analysis, students' ability, narrative Text

\section{INTRODUCTION}

The ability in using language is a human special treatment that differentiates from the other God's creatures. So that, they must take care and create the human special treatment that differentiates from the other God's creatures language skill for the sake of life. Mastery of language is very important because everything can be communicated by using language. English can be learned in almost all books, internet media, and in general. Therefore, a good understanding is very important in the era of globalization.

There are four skills are listening, speaking, reading, and writing. Reading is a really important language skill, especially for students. It is said so because the 2013 Curriculum of junior and senior high schools curriculum requires students to be able to read some kind of genre in reading. That is why the students' reading ability needs 
to be trained since they are still at the early age of education.

Reading is a gate of knowledge. It is said so because people can get much knowledge or information by reading. Brown (2001:299-300) that the readers understand what they read because they are able to take the stimulus beyond its graphic representation and assign its membership to an appropriate group of concepts already stored in their memories skill in reading depends on the efficient interaction between linguistics knowledge of the world. Afflerbach (2007: 12-13) says as quoted by Dewi (2013) that reading is a dynamic and complex process that involves skills, strategies, and prior knowledge. Reading is a skill for learners as a second language (Nunan, 2003). Reading is important skill ought to be acquired by students to ensure success in both learning English and any content area. Reading is not as easy as in mind. There are many sentences in paragraphs are involved which need to analyze to absorb the meaning of the paragraph. Understand the meaning of a paragraph is needed a continuous training. Students who have been usual to read will not get any difficulties understanding the meaning of the paragraph. Eskey (2002) defines that reading is the process of obtaining information from written or printed text. Students who have a reading habit will find it easier to understand the meaning of writing and always know new terms or words. The students also can understand the new words in their context in sentences. The reason for the researcher choosing this topic is: (1) The students who lack reading will find it difficult to understand and identify the main idea in a narrative paragraph. (2) The students who do not understand new words in the paragraph. Cause a problem to the reading process that also retard the students' reading skills.

Hasani (2005:22) stated that narrative is conversation or writing with the purpose tells about action or human experience based on the development of time. Keraf (1991:136) stated that "Narrative as a story tells or describe an action in the past time clearly, so narrative is tried to answer the question: what happened". It's mean that the Narrative paragraph is a story that tells a series of events experienced by the narrator. The story is usually taken from the beginning, middle, and end, which is a continuous and definite event. The order of presentation in the narrative text of the story is very important for the unity of the paragraph as a whole. The Narrative paragraph it self is structure by three elements, namely the topic sentence, main idea, and supporting sentence. The topic sentence is a point of view to describe 
the sentence contained in the expository paragraph that summarizes the whole main idea of the paragraph. The main idea is what that the paragraph is about supporting sentence is the sentences with in a paragraph that support the topic sentence. Understanding the structure of the text of the reading text is very helpful for the reader in determining the main idea. Broek et al. (2003) explored readers' ability to pinpoint main in narrative texts and the growth of this skill. In particular, the authors tasted students' understanding of the narrative paragraph goal system.

According to Mc Whorther (1989) the main idea is called the topic sentence. She adds that the main idea is not explicitly stated any one sentence. Instead, it is left to the reader to infer, or the reason out. The main idea is a sentence that covers an entire paragraph of ideas. Barron (1995: 302) says that "the main idea usually comes at the beginning of the section". Raygor (1969: 2) says that "the main idea is expressed in one statement which summarizes all the ideas in the paragraph, not just a part. Crawley and Merritt (2000:54) said that "The main idea is the central thought or meaning of a passage or selection: the main topic of the passage selection. it may be expressed or implied. if the main ideas are stated directly, they are at the level of factual understanding. Leopold and Leutner (2012) conducted research related to the problem of finding the main idea. They focus on strategies for dealing with the main idea. But this research focuses on the problems in finding main idea.

Brown (1987: 203) says that if you get the main idea, you can make some incredible conclusions about details you never even read. That is the reason it is very important to understand the contents of the reading in advance so that it is easier to find out the main ideas. Identifying the main idea of a paragraph helps students interpret what a writer is saying through his writing. Based on the description above, researchers need to analyze students' abilities in identifying main ideas.

Based on the explanation above the writer decided to do research entitled "An Analysis of students' Ability In Identifying Main Idea In Narrative Paragraph Of The First Grade At SMA PUTERI SION MEDAN".

\section{METHOD}

In this research, the author searches for and studies the many theories needed as a guide for understanding to explain the concepts or terms applied by the author regarding the ideas and terms used in the research to obtain the required data. This chapter describes how the methods used in research. Starting from the research 
design, research subjects, research locations, data collection instruments, data collection procedures, and data analysis.

This study, the researcher used a qualitative method that analyzed the facts from the study, which was used to identify the students' ability to in identifying the main idea in narrative paragraphs. The writer will visit a school for research and obtain data on the students' information that will be identified by the researcher.

The study was conducted at SMA PUTERI SION MEDAN. As research subjects were grade 1 student of SMA PUTERI SION MEDAN. The Researcher chose the first-grade students of SMA PUTERI SION MEDAN as research subjects for reasons the consideration that grade 1 has learned about identify this topic. The researcher chose this school because no researcher had done previous research at this school on this topic.

The object of this research is the ability to identify main ideas in narrative paragraphs carried out by students.

The instrument used by researchers in this study was a test. The test used is a written test. The researcher gave three narrative texts then the students were given a test to identify the main idea in the narrative paragraph. Researchers will provide various kinds of questions. Each correct answer is awarded 5 points and the wrong answer does not affect the score. In terms of collecting the data, the researcher designs the following steps:

1. Prepare for the test.

2. Give the explanation and direction of how to answer the test.

3. Distribute questions/test

4. Give time

5. Collect the test.

This research is a qualitative study using an analysis technique used by the researcher is to use the criteria formula that must be obtained is ranging from 70-100 formulas used to calculate the criteria that will prove how the students' ability to identify narrative paragraphs ideas.

The research data were analyzed using the following procedures:

1. The author checks the students' answer sheets.

2. The author gives the score, by using this formula. 
3. Arikunto (2002:236) said that if the researcher just wants to know the result of the data analysis, it can be used by the researcher her/himself without used computer. The result can be read clearly and it is can be conclude with easy. So, to calculate the percentage of the students' ability the researcher using formula:

$$
\mathrm{S}=\frac{\mathrm{R}}{\mathrm{N}} \times 100
$$

Where:

$\mathrm{S}=$ Score number of the test item.

$\mathrm{R}=$ The number of correct or incorrect answer.

$\mathrm{N}=$ The number of the test item.

\section{Example:}

The students who get the correct answer 5 from 6 items, so to find percentages' ability by using that formula

$$
\begin{aligned}
& S=\underline{5} \times 100 \\
& \quad 6 \\
& =83,3
\end{aligned}
$$

4. Measuring the percentage of those who are able and unable students.

After derived the score the writer was classified the students' ability in identifying the main idea. The scale by using the following criteria proposed by Heaton (1998:317) states that "the students who get the average more than 60 would have predicate able, and the students who get the average less than 60 would have the predicate unable". Then, for identifying the criteria of ability and inability of the students, are as follows.

Table 1.1 Level of Ability

\begin{tabular}{|c|c|c|c|}
\hline Number & $\begin{array}{c}\text { Quantitative } \\
\text { Ability }\end{array}$ & $\begin{array}{c}\text { Qualitative } \\
\text { Ability }\end{array}$ & Ability \\
\hline 1 & $91-100$ & Excellent & Able \\
\hline 2 & $81-90$ & Very good & Able \\
\hline 3 & $71-80$ & Good & Able \\
\hline 4 & $61-70$ & Enough & Able \\
\hline 5 & $51-60$ & Bad & Unable \\
\hline 6 & Less than 50 & Very bad & Unable \\
\hline 7 & 0 & Fail & Unable \\
\hline
\end{tabular}




\section{FINDING \& DISCUSSION}

\section{Finding}

Before analyzing the data, the researcher collected the results of the students' written tests which were done individually. Research data is in the form of a score based on the number of items answered correctly, the researcher applies the system by providing a value for each correct answer, and for wrong answers it will not affect the value of the correct answer. The following is a table of the number of students who received correct and incorrect answers on the test

Table I

\section{Students' Correct Answer}

\begin{tabular}{|c|c|c|}
\hline No & Students & Correct answer \\
\hline 1. & Debora & 5 \\
\hline 2. & Sindi & 5 \\
\hline 3. & Maria & 5 \\
\hline 4. & Rendy & 4 \\
\hline 5. & Rizky & 3 \\
\hline 7. & Linda & 2 \\
\hline 8. & Johannes & 2 \\
\hline 9. & Noverman & 2 \\
\hline 10. & Beri & 2 \\
\hline 11. & Jerico & 2 \\
\hline
\end{tabular}

Table II

Table of Students' Score with category in identifying the main idea in Narrative Text

\begin{tabular}{|c|c|c|c|}
\hline No & Students & Scores & Category \\
\hline 1. & Debora & 83,3 & Very good \\
\hline
\end{tabular}




\begin{tabular}{|r|c|c|c|}
\hline 2. & Sindi & 83,3 & Very good \\
\hline 3. & Maria & 83,3 & Very good \\
\hline 4. & Rendy & 66,6 & Enough \\
\hline 5. & Rizky & 60 & Bad \\
\hline 6. & Khatarina & 50 & Bad \\
\hline 7. & Linda & 33,3 & Very bad \\
\hline 8. & Johannes & 33,3 & Very bad \\
\hline 9. & Noverman & 33,3 & Very bad \\
\hline 10. & Beri & 33,3 & Very bad \\
\hline
\end{tabular}

Table III

Table the classification Percentage

\begin{tabular}{|c|c|c|c|}
\hline No. & Category & Frequency & Percentages \\
\hline 1. & Excellent & 0 & $0 \%$ \\
\hline 2. & Very good & 3 & $27,28 \%$ \\
\hline 3. & Good & 0 & $0 \%$ \\
\hline 4. & Enough & 1 & $9,09 \%$ \\
\hline 5. & Bad & 2 & $18,18 \%$ \\
\hline 6. & Very bad & 5 & $45,45 \%$ \\
\hline 7. & Fail & 0 & $0 \%$ \\
\hline \multicolumn{2}{|r|}{ Total } & 11 & $100 \%$ \\
\hline
\end{tabular}

After finishing analyzing the data, the researcher concluded that the percentage of students' abilities in identifying main ideas in paragraphs of narrative text was as follows:
A. Excellent category are on percentage $0 \%$
B. Very good category are on percentage $27,28 \%$
C. Good category are on percentage $0 \%$
D. Enough category are on percentage $9,09 \%$
E. Bad category are on percentage $18,18 \%$
F. Very bad category are on percentage $45,45 \%$
G. Fail category are on percentage $0 \%$.

Based on the student score table in identifying the main idea in the narrative paragraph. There were 11 students sampled by the researcher to analyze the ability to identify main ideas in narrative paragraphs. The researcher concluded based on the data that if you look at the data from the table above, it is still difficult for grade 11 high school students to identify the main idea in a narrative paragraph. This is evidenced by unsatisfactory student results. From the first table, it can be concluded that there are only 3 students in the very good category, namely 1 student in the sufficient category, 2 students in the bad category and there are 5 students in the very bad category. From 
the results of this study, the researcher found that many problems made it difficult for 10th-grade high school students to identify the main ideas in narrative text, namely: 1. Lack of students' reading interest. Reading can be interpreted as something interesting that someone does, without having to look at the elements in reading and vocabulary is a major component of reading ability and this will make it difficult for readers to understand reading. 2. Lack of knowledge of vocabulary. Vocabulary is the main thing in reading. The ability to read will make language learners have difficulty. The level of difficulty given will vary according to the text guide. Then 3. Bad reading strategies. This means that to make it easier to identify main ideas in narrative text, a good understanding of reading strategies is needed.

\section{DISCUSSION}

Researchers have conducted research on class x Puteri Sion Medan with a total of 11 people. Researchers only provide text that contains narrative paragraphs. It aims to analyze students 'abilities and find out students' difficulties in identifying the main idea of narrative paragraph text. The test is conducted in the classroom. With this process, researchers can find out the value of identifying student paragraph main ideas through text sheets containing narrative paragraphs given to students. After finishing analyzing the data, it was found that students who scored 60 and below were more than students who scored 60 and above. In this case, if the student's score is 60 and below, it means that the student has difficulty identifying the main idea in the narrative paragraph. Based on data analysis conducted, it was found that most values were categorized as very bad with a percentage of $45.45 \%$. In this study, it is necessary to understand 3 types of the location of the main ideas in a paragraph, namely inductive, deductive, and mixed. If students do not understand the location of the main ideas, students will find it difficult to determine the main ideas in a paragraph. After analyzing the data, the researcher found many problems that made it difficult for class X SMA students to identify the main ideas in the narrative text, namely the students' lack of reading interest. Reading can be interpreted as something interesting that someone does, without having to look at the elements in reading and vocabulary which are the main components of reading ability and this will make it difficult for readers to understand reading, lack of vocabulary knowledge is the main thing in reading ability, this will make it difficult for language learners. The level of difficulty given will vary according to the manual text, and poor reading strategies. 
This means that to facilitate the identification of main ideas in narrative text, a good understanding of reading strategies is required.

\section{CONCLUSION}

Based on the results of the research conducted, the researcher concluded that the students' ability to determine the main idea of narrative text paragraphs was in a very bad category because from the overall test results students did not understand how to identify the main idea in narrative text. The results showed that the ability to understand the content of the narrative text and good strategies in reading the narrative text was classified as very bad, with the highest score with a percentage of $45.45 \%$. This is because the difficulties experienced by students are the lack of understanding of the reading content in the narrative text even though they have received directions from the teacher and only received a little material from the researcher.

\section{REFERENCES}

Afflerbach, P. 2007. Understanding and Using Reading Assesment K-12. University of Maryland: College Rark.

Arikunto, S. 2002. Prosedur Penelitian Suatu Pendekatan Praktis. Jakarta: Rieneka Cipta.

Barron's. 1995. Preparation Guide. United States of America: McGraw-Hill Book Companies.

Broek, V.D, P; Lynch, J S.; Naslund, J; Ievers-Landis, C. E.; Verduin, K.(2003). The development of comprehension of main ideas in narratives: evidence from the selection of titles. Journal of Educational Psychology, 95(4), 707-718.

Brown, J.D. 2001. Teaching by Principles an Interactive Approach to Language Pedagogy. New York: Longman.

Crawley, J, Sharon and Merritt, King. 2000. Remedieting Reading. United States of America: The McGraw-Hill Companies.

Eskey, D., E. 2002. Reading and the Teaching of L2 Reading. TESOL Journal Vol. 11 No. 1.

Hasani, Aceng. 2005. Ihwal Menulis. UNTIRTA PRESS.

Heaton, J. B. 1998. Writing English Language Test. London: Longman. 
Keraf, Gorys. 1991. Argumentasi dan Narasi. Jakarta: PT. Gramedia.

Leopold, C. and Leutner, D. 2012. Science Text Comprehension: Drawing Main Idea Selection and Summarizing as Learning Strategies. Learning and Instruction Vol. 22.

Mc Whorter, Kathleen. T. 1989. College Reading Study Skills. London: Scott, Foresman and Company.

Mc Whorter, Kathleen. T. 1989. Guide to College Reading. New York: Harper Collins Publishers.

Nunan, David. 2003. Practical English Language Teaching. New York: The McGrawHill Companies.

Raygor, L, Alton. 1969. Reading for the Main Idea. United States of America: McGraw- Hill Book Company. 